\title{
Professor Christopher Nordin: in memoriam
}

\author{
Bill Robertson · Graham Russell
}

Received: 24 November 2014 / Accepted: 27 November 2014 / Published online: 23 December 2014

(C) Springer-Verlag Berlin Heidelberg 2014

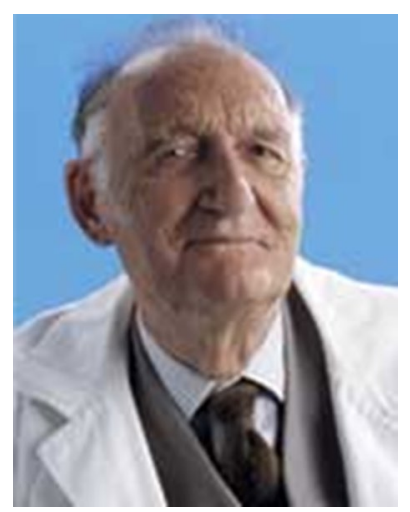

It was with great sadness that we learned of the death of Professor Christopher (Chris) Nordin on 27th October 2014 in Adelaide at the age of 94. His death is a great loss, not only to his close family but also to the whole "calcium community". Although his main research interests were always in disorders of calcium metabolism and bone disease, he fostered research in many related areas of research, including urolithiasis.

Chris graduated in medicine at the University of London in 1950, having previously been a British translator in Sweden during the Second World War before returning to the UK to complete his medical studies. He specialised in endocrinology and held an appointment at the Hammersmith Hospital in London where he first developed what was to become his lifelong interest in calcium metabolism

B. Robertson $(\bowtie)$

Oxford, UK

e-mail: robertsonwilliam67@gmail.com

G. Russell

Sheffield, UK and bone disease. Later he held a Lectureship in the Gardiner Institute in Glasgow Western Infirmary where I (WGR) joined him as a PhD student in 1963 to carry out research on the physical chemical aspects of stone-formation. Exactly a year later, Chris was appointed as Director of the new MRC Mineral Metabolism Research Unit (later re-named the MRC Mineral Metabolism Unit) in the General Infirmary at Leeds and I was fortunate to be invited to accompany him in order to complete the research for my thesis. (The dropping of the word "Research" in the title of the Unit caused no little amusement among Chris's competitors in the calcium world but the purpose of this was to alleviate any patient fears that they might be used as guinea pigs rather than to suggest that no research would be carried out in the Unit!) The new Unit took the place of the pre-existing Research Unit for Metabolism Disturbances in Surgery (also supported by the MRC) when its Director (Professor Leslie Pyrah, a pioneering urologist famous for his research into primary hyperparathyroidism and renal stone disease) retired. One of us (RGGR) was already studying for a $\mathrm{PhD}$ in Leslie Pyrah's Unit, under the supervision of the late Albert Hodgkinson, on the role of inhibitors of crystallisation, particularly pyrophosphate, in the prevention of stone-formation. So, both of us were involved from different sources in the inception of the embryonic Mineral Metabolism Unit under its new Director.

As Director of the MMU, Chris soon earned an international reputation for his research into disorders of calcium metabolism and bone disease, particularly osteoporosis. However, he retained a lively interest in urolithiasis to the extent that about a quarter of the Unit's resources were directed to support research in that field. This included the establishment of a specialised Stone Clinic run by Munro Peacock (now Professor of Medicine in Indianapolis). In 1968, along with Albert Hodgkinson, Chris organised in 
Leeds what was to become the first of the series of International Symposia on Urolithiasis which have since been held every 4 years in various locations throughout the world [Madrid (1972), Davos (1976), Williamsburg (1980), Garmisch-Partenkirchen (1984), Vancouver (1988), Cairns (1992), Dallas (1996), Cape Town (2000), Hong Kong (2004), Nice (2008) and, most recently, in Ouro Preto (2012)]. As PhD students in the MMU at the time, we both had the honour of presenting papers at that first Symposium in Leeds. Regrettably, many of the other participants in that Symposium who were, or later became, top researchers in the field of urolithiasis have sadly since passed on. These include pioneers in bone and stone research such as David Andersen, Norman Blacklock, Bill Boyce, James Elliott, Herbie Fleisch, Albert Hodgkinson, Dame Kathleen Lonsdale, Monte Modlin, Leslie Pyrah, Lyn Smith, Bill Stanbury, Roger Sutton, Bill Thomas, Richard Watts and Bob Williams.

Chris was an inspirational teacher and staunch supporter of those who worked for him. He had a brilliant and incisive mind and could cut to the core of any debate on all matters scientific, medical and political. He had a great capacity to stimulate and enthuse others and he rapidly built the Unit into a thriving centre for bone and stone research. In 1967, together with Fred Pautard, he launched 'Calcified Tissue Research' (now Calcified Tissue International) a then new journal in the field of calcium metabolism and bone disease. Initially accorded Honorary Senior Lecturer status at the University of Leeds, Chris was made Reader in 1965 and was awarded a personal Chair in 1970.
In 1981, at the age of 61 , Chris took early retirement from the MRC and moved to Adelaide to take up a senior research appointment where he continued to be active clinically whilst embarking on a second career in research into disorders of calcium metabolism and bone disease at the Royal Adelaide Hospital, the University of Adelaide and the Institute of Medical and Veterinary Science - a career which was to last for a further three decades. In 1998, he received the Frederic $\mathrm{C}$ Barter award of the American Society for Bone and Mineral Research and later was made an Officer of the Order of Australia for his services to medical research in 2007. During the latter phase of his career, he continued to work on the importance of the renal excretion of calcium in the maintenance of bone health and was author of the WHO/FAO Dietary Calcium Recommendations report which was adopted in Australia and New Zealand.

Speaking personally (WGR) and looking back over my own career in research, the 21 years that I spent in Leeds undoubtedly comprised the happiest and most productive period of my life. There are many occasions after I left Leeds when I would have liked to have been able to knock on Chris's door and ask him for his advice which would always have been helpful and instructive. It was an honour and privilege to have known him and to have worked with him directly during part of his long and distinguished career.

Professor Nordin will be missed by colleagues in the calcium and associated fields throughout the world and at this difficult time our thoughts and support go out to his family. 